\title{
Clean Development Mechanism in Sewage Treatment Plants
}

\author{
Suresh Kumar D ${ }^{1}$, Dr. V. Sekaran ${ }^{2}$ \\ ${ }^{1}$ PhD Scholar, Department of Civil Engineering, Karpagam University, Coimbatore, India, \\ ${ }^{2}$ Principal, Raja College of Engineering \& Technology, Madurai, India,
}

\begin{abstract}
Climate change, currently the biggest threat that the world is facing today has impacts on different sectors such as agriculture, energy, forestry and health. United Nations Framework Conservation on Climate Change was formed to mitigate these threats. Parties to the conservation met at Kyoto, Japan and approved Clean Development Mechanism to combat Green house gas emissions. India has a vast opportunity to explore in terms of CDM and carbon-credits. Through its giant ongoing Infrastructure projects and projects on nonconventional energy sources, a new phase of development is still to be observed, moderate start of which has already begun. One of the projects, which is being applied for CDM is methane collection and utilization from sewage water treatment facilities. The objective of this paper is to identify the size of opportunities for gaining carbon credit through sewage treatment plants.
\end{abstract}

Keywords --- Biogas, Carbon Credit, CDM, Global Warming, Kyoto Protocol

\subsection{Global Warming}

\section{Introduction}

The Earth has an atmosphere of the proper depth and chemical composition. About $30 \%$ of incoming energy from the sun is reflected back to space while the rest reaches the earth, resulting in warming the air, oceans, and land, and maintaining an average surface temperature of about $15^{\circ} \mathrm{C}$. The chemical composition of the atmosphere is also responsible for nurturing life on our planet. Most of it is nitrogen (78\%); about $21 \%$ is oxygen, which all animals need to survive; and only a small percentage $(0.036 \%)$ is made up of carbon dioxide which plants require for photosynthesis. The atmosphere carries out the critical function of maintaining lifesustaining conditions on Earth, in the following way: each day, energy from the sun is absorbed by the land, seas, mountains, etc. If all this energy were to be absorbed completely, the earth would gradually become hotter and hotter. But actually, the earth both absorbs and, simultaneously releases it in the form of infra red waves. All this rising heat is not lost to space, but is partly absorbed by some gases present in very small (or trace) quantities in the atmosphere, called greenhouse gases (GHGs). Greenhouse gases (for example, carbon dioxide $\left(\mathrm{CO}_{2}\right)$, methane $\left(\mathrm{CH}_{4}\right)$, nitrous oxide $\left(\mathrm{N}_{2} \mathrm{O}\right)$, water vapour), re-emit some of this heat to the earth's surface. If they did not perform this useful function, most of the heat energy would escape, leaving the earth cold (about $18^{\circ} \mathrm{C}$ ) and unfit to support life.

As the GHGs are transparent to incoming solar radiation, but opaque to outgoing longwave radiation, an increase in the levels of GHGs could lead to greater warming, which, in turn, could have an impact on the world's climate, leading to the phenomenon known as climate change. Indeed, scientists have observed that over the 20th century, the mean global surface temperature increased by $0.6^{\circ} \mathrm{C}$

Important greenhouse gases are: water vapour ,carbon dioxide $\left(\mathrm{CO}_{2}\right)$, methane $\left(\mathrm{CH}_{4}\right)$, nitrous oxide $\left(\mathrm{N}_{2} \mathrm{O}\right)$, hydrofluorocarbons (HFC), perfluorocarbons (PFC), and sulfur hexafluoride $\left(\mathrm{SF}_{6}\right)$. Carbon dioxide is used as the benchmark, so all other gases are measured in carbon dioxide equivalence $\left(\mathrm{CO}_{2} \mathrm{e}\right)$.

Table I

The global warming potential of six major greenhouse gases

\begin{tabular}{|l|l|l|}
\hline Name of the Gas & $\begin{array}{l}\text { Global } \\
\text { Warming } \\
\text { Potential }\end{array}$ & $\begin{array}{l}\text { Atmospheric Life } \\
\text { (years) }\end{array}$ \\
\hline Water Vapour $\left(\mathrm{H}_{2} \mathrm{O}\right)$ & 0.1 to 0.23 & Few days \\
\hline Carbon dioxide $\left(\mathrm{CO}_{2}\right)$ & 1 & 5 to 200 \\
\hline Methane $\left(\mathrm{CH}_{4}\right)$ & 21 & 12 \\
\hline Nitrous oxide $\left(\mathrm{N}_{2} \mathrm{O}\right)$ & 310 & 114 \\
\hline Hydrofluorocarbons $(\mathrm{HFC})$ & 140 to 11,700 & 1.4 to 260 \\
\hline Perfluorocarbons $(\mathrm{PFC})$ & 6,500 to 9,200 & 10,000 to $50,000+$ \\
\hline Sulfur hexafluoride $\left(\mathrm{SF}_{6}\right)$ & 23,900 & 3200 \\
\hline
\end{tabular}




\subsection{Kyoto Protocol}

In 1992 famous Rio earth summit, United Nation Framework Convention on Climate Change (UNFCCC) was adopted with an objective to stabilize atmospheric concentration of GHG at levels that would prevent dangerous humane interference with climate system. The UNFCCC came into effect on 21st March, 1994 according to which industrialized countries shall have the main responsibility to mitigate climate change. Such countries are listed as Annex- I countries. Under UNFCCC all the member countries were to report on their national GHG emissions inventories and propose climate change mitigation strategies. After two and half years of intense negotiation between Annex-I countries, an agreement was struck at the Kyoto protocol on 11 December 1997 in Kyoto, Japan. The convention, participated by 160 countries of the world, was to negotiate binding limitations on greenhouse gases for the developed nations pursuant to the objective of the Framework Convention on Climate Change of 1992.

\subsection{Clean Development Mechanism}

Under the Kyoto Protocol, emission caps were set for each Annex-I countries, amounting in total to an average reduction of 5.2\% below the aggregate emission level in 1990. Each country has a predetermined target of emission reduction as compared to 1990 level. No emission cap is imposed on Non - Annex I countries. However, to encourage the participation of Non-Annex I in emission reduction process a mechanism known as Clean Development Mechanism (CDM) has been provided. The carbon markets are a prominent part of the response to climate change and have an opportunity to demonstrate that they can be a credible and central tool for future climate mitigation. The outcome was the Kyoto Protocol, in which the developed nations agreed to limit their greenhouse gas emissions, relative to the levels emitted in 1990 or pay a price to those that do. At this point comes the carbon trading.

\subsection{Carbon Credits}

The primary purpose of the Protocol was to make developed countries pay for their ways with emissions while at the same time monetarily rewarding countries with good behaviour in this regard. This system poises to become a big machine for partially transferring wealth from wealthy, industrialised countries to poor, undeveloped countries. A CER or carbon Credit is defined as the unit related to reduction of 1 tonne of $\mathrm{CO}_{2}$ emission from the baseline of the project activity.

Let us say that India decided to invest in a new power station, and has decided on a particular technology at the cost of X crore. An entity from an industrialised country (which could even be a company) offers to provide India with slightly better technology, which costs more (say Y crore), but will result in lower emissions. The industrialised country will only pay the incremental cost of the project - viz. Y minus X. In return, the investing country will get certified emission reductions (CERs), or credits, which it can use to meet its Kyoto commitments. This is a very good deal indeed - but for the investing country. Not only do they sell developing countries their technology, but they also meet their Kyoto commitments without lifting a finger to reduce their domestic emissions. Countries like the US can continue to pollute at home, so long as it makes the reductions elsewhere.

The World Bank has built itself a role in this market as a referee, broker and macro-manager of international fund flows. The scheme has been entitled Clean Development Mechanism, or more commonly, Carbon Trading.

\subsection{CDM Project Types}

Type of projects, which are being applied for CDM and which can be of valuable potential, are:

- Energy efficiency projects

- Increasing building efficiency (Concept of Green Building/LEED Rating)

- Increasing commercial/industrial energy efficiency (Renovation \& Modernization of old power plants)

- Fuel switching from more carbon intensive fuels to less carbon intensive fuels; and

- Also includes re-powering, upgrading instrumentation, controls, and/or equipment

- Transport

- Improvements in vehicle fuel efficiency by the introduction of new technologies

- Changes in vehicles and/or fuel type, for example, switch to electric cars or fuel cell vehicles (CNG/Bio fuels)

- Switch of transport mode, e.g. changing to less carbon intensive means of transport like trains (Metro in

Delhi); and

- Reducing the frequency of the transport activity

- Methane recovery

- Animal waste methane recovery \& utilization

- Installing an anaerobic digester \& utilizing methane to produce energy

- Coal mine methane recovery 
- Collection \& utilization of fugitive methane from coal mining;

- Capture of biogas

- Landfill methane recovery and utilization

- Capture \& utilization of fugitive gas from gas pipelines;

- Methane collection and utilization from sewage/industrial waste treatment facilities

- Industrial process changes

Any industrial process change resulting in the reduction of any category greenhouse gas emissions

- Cogeneration

-Use of waste heat from electric generation, such as exhaust from gas turbines, for industrial purposes or heating (e.g. Distillery-Molasses/ bagasse)

- Agricultural sector

- Energy efficiency improvements or switching to less carbon intensive energy sources for water pumps (irrigation)

- Methane reductions in rice cultivation

- Reducing animal waste or using produced animal waste for energy generation and

- Any other changes in an agricultural practices resulting in reduction of any category of greenhouse gas emissions

\title{
1.6 Indian Scenario- Favouring Points
}

a) India - high potential of carbon credits

b) India can capture $10 \%$ of Global CDM market

c) Annual revenue estimated range from US $\$ 10$ million to 330 million

d) Wide spectrum of projects with different sizes

e) Vast technical human resource

f) Strong industrial base

\subsection{Biogas Recovery from Sewage Treatment Plants}

Biologically produced energy has been identified as an attractive alternative to the increasingly scarce fossil fuel supplies. Resource recovery from waste fetches revenue and makes the environment safe and healthy. Since the Energy Recovery from Sewage Treatment Plants is of the nature of 'non conventional' i.e. 'renewable energy source', it is eco friendly and increases sustainability.

Anaerobic fermentation of organic waste leading to biogas generation is one such process which has considerable potential to supplement energy supplies. Apart from the economic advantages, biogas recycling has great environmental benefits because primary material can be saved and pollution loads from conventionally produced energy can be minimized. The use of renewable energy makes the environment 'clean and green'.

1.8 Direct Benefits of Treatment Plants Designed for Resource Recovery

Sewage treatment plants designed for resource recovery are less expensive to operate than traditional aerobic plants. We need the right kind of sewage treatment. Traditional treatment relies on aerobic micro organisms to convert the organic energy in wastewater to carbon dioxide and biomass (sludge). The process consumes significant amounts of chemicals and electricity, but consuming electrical energy to get rid of organic energy is senseless;

In anaerobic treatment plants on the other hand, methanogenic bacteria digest organic materials and produce raw biogas - a mixture of roughly $1 / 3 \mathrm{CO}_{2}$ and $2 / 3$ methane. When the raw gas is stripped of $\mathrm{CO}_{2}$ and trace sulphur compounds (using treated wastewater) the resulting natural gas can be used as renewable energy. Anaerobic treatment plants cost less to build since they do not require aeration equipment, and they require less space since they use closed vessels rather than open settling tanks. They also cost less to operate since they do not consume electricity for aeration and use fewer chemicals; aerobic plants require settling agents such as alum and commonly use chlorine to disinfect sludge and effluent. Finally, anaerobic plants produce one fifth to one twentieth of the sludge produced by aerobic plants, since a significant proportion of the energy in the wastewater is converted to methane. Since anaerobic treatment takes place in closed vessels, odours are contained and it becomes practical to co-locate treatment with other land uses.

\author{
1.9 Classification of Secondary Treatment \\ 1).Aerobic Treatment Units \\ a)Suspended Growth \\ - Activated Sludge Process (ASP), \\ - Sequencing Batch Reactor (SBR), \\ - Aerated Lagoon (AL), \\ - Extended Aeration Process (EA)
}


- Membrane Biological Reactors (MBR)

b)Attached Growth

- Trickling Filters (TF),

- Rotating Biological Contactors (RBC),

- Fluidized aerobic bed bioreactors (FAB)

2) Anaerobic Treatment Units

a) Suspended Growth:

- Batch Fed (BF),

- Once or Intermittent Fed (OIF),

- Continuous Stirred Reactor -Fed daily with solid recycle

(CSR),

$\square$ Up-flow Anaerobic Sludge Blanket (UASB),

- Baffle Reactor-Fed daily without solid recycle (BR),

- Continuous Stirred Tank Reactor (CSTR),

- Plug Flow

b) Attached Growth:

- Expanded Bed EB),

- Anaerobic Fluidized Bed (AFB),

- Anaerobic Filters (AF),

- Rotating Biological Disc (RBD)

3) Aerobic and Anaerobic in Tandem

- Biofilter

The ASP and UASB based sewage treatment plant are biogas producing plants. The FAB, SBR and WSP based plants are not capable of producing biogas.

\subsection{Composition of Biogas}

Biogas is a colorless, odorless, inflammable gas, produced by organic waste and biomass decomposition (fermentation). Biogas can be produced from animal, human and plant (crop) wastes, weeds, grasses, vines, leaves, aquatic plants and crop residues etc. The composition of different gases in biogas is as below:

- Methane (CH4): 55-75\%

- Carbon Dioxide (CO2): 25-45\%

- Hydrogen Sulphide (H2S): 0.1-0.5\%

- Nitrogen (N2): $1-5 \%$

- Hydrogen (H2): 0-3\%

- Carbon Mono Oxide (CO): 0-0.3\%

- Oxygen (O2): Traces

\subsection{Sewage Treatment Plants at Chennai}

\section{Materials and Methods}

Chennai Metropolitan Water supply and Sewerage Board (CMWSSB) has been established in 1978 under an Act of Tamil Nadu (Act 28) as a statuary body for exclusively attending to the growing needs and for planned development and appropriate regulation on water supply and sewerage services in the Chennai Metropolitan Area (CMA) in the particular reference to the protection of public health and all the matters connected therewith or incidental thereto. With effective need based and situational management, by adopting opt strategies potable water is being distributed and the used water (sewage) is being collected systematically, pumped to the Sewage Treatment Plant (STP) for safe disposal of the treated sewage to the water ways as prescribed by the PCB thereby the environmental is being not harmed at the same time quality of life of the people also improved.

The wastewater system for the city has been divided into 5 zones; These Zones of macro systems covering the entire City had independent Zonal collections, conveyance, and treatment and disposal facilities. 
Table II

Sewage Treatment Plants at Chennai

\begin{tabular}{|c|c|c|c|c|}
\hline \multirow{2}{*}{ Zone No } & \multirow{2}{*}{$\begin{array}{c}\text { Name of The } \\
\text { Zano }\end{array}$} & \multicolumn{3}{|c|}{ Capacity of The Plant (MLD) } \\
\cline { 3 - 4 } & Old & New & Total \\
\hline I & Kodunkaiyur & 80 & 110 & 270 \\
\hline II & Kodunkaiyur & 80 & & \\
\hline III & Koyumbedu & 34 & 60 & 94 \\
\hline IV & Nesappakkam & 23 & 40 & 63 \\
\hline V & Perungudi & - & 114 & 114 \\
\hline & Total & 217 & 324 & 541 \\
\hline
\end{tabular}

All the plants are of Activated Sludge Process technology. The old plants are not having gas engine facility. The produced gases are simply flared up. Only the new plants having the facility of gas engine which converts the methane in to electricity.

\subsection{Quantifying GHG Emission Reductions}

Emission reductions are assumed to be the amount of methane that would be emitted during the crediting period in the absence of the agricultural methane Project (minus Project emissions). For each year during the crediting period, Project Proponents shall compare the actual metered methane destruction values and ex-ante modeled estimates of methane destruction. Project Proponents shall claim emission reductions only for the lesser of the two values.

Calculations for Metered Methane Destruction

Tabulated records of total daily agricultural methane gas flows (in standard cubic feet per day) shall be matched with either the continuous methane content data or with the associated periodic reading to methane recovery rates, using Equation 1:

Equation 1: CH4 Recovered

$\mathrm{CH} 4$ recovered $=$ BGrecovered $\mathrm{x} \% \mathrm{CH} 4$

Where:

$\mathrm{CH} 4$ recovered $=$ Methane recovered per day (as measured in standard $\mathrm{ft} 3 /$ day)

BGrecovered $=$ Biogas recovered per day (as measured in standard $\mathrm{ft} 3 /$ day)

$\% \mathrm{CH} 4=$ Methane content of biogas

Methane flows shall be tabulated and summed on a monthly basis using the continuous daily readings for flow and the appropriate methane content readings.

Equation 2: $\mathrm{CH} 4$ Combusted

In order to estimate the amount of methane combusted in metric tons per year $(\mathrm{Mg} / \mathrm{yr})$, the annual methane recovery rate in cubic feet per year needs to be converted to weight using Equation 2:

$\mathrm{CH} 4$ combusted $=\left(\mathrm{CH} 4\right.$ recovered $\left.\mathrm{x} 16.04 \times\left[1 / 10^{6}\right] *[1 / 24.04] \times 28.32\right) * \mathrm{DE}$

Where:

$\mathrm{CH} 4$ combusted = Annual methane combusted (as measured in $\mathrm{Mg} / \mathrm{yr}$ )

$\mathrm{CH} 4$ recovered = Annual methane recovered (as measured in $\mathrm{ft} 3 / \mathrm{yr}$ )

16.04 = molecular weight of $\mathrm{CH} 4$

$1 / 10^{6}=$ Conversion to metric tons $(\mathrm{Mg} / \mathrm{g})$

$1 / 24.04=$ Gas constant $(\mathrm{mol} / \mathrm{L}-$ measured at standard temperature and pressure - defined as $68 \mathrm{~F}$ and

$14.7 \mathrm{psi}) 14$

$28.32=$ Conversion factor $(\mathrm{L} / \mathrm{cf})$

$\mathrm{DE} \quad=$ Destruction efficiency of the destruction device (default value of $98 \%$ )

Calculation of Project Emissions

Depending on Project-specific circumstances, certain emissions sources may need to be

subtracted from total Project emission reductions using the equations below.

Equation 3a: $\mathrm{CO} 2$ Emissions from Fossil Fuel Combustion

DestCO2 $=\Sigma y(F F y * E F y)$

Where:

DestCO2 $=\mathrm{CO} 2$ emissions from fossil fuel used in methane destruction process $(\mathrm{tCO} 2)$

FFy $\quad=$ Total quantity of fossil fuel, $y$, consumed (as measured in volume of fuel)

EFy $\quad=$ Fuel specific emission factor for fuel, y (as measured in $\mathrm{tCO} /$ /fuel quantity - values should be taken from The CCX GHG Emissions Factors online document)

Equation 3b: $\mathrm{CO} 2$ emissions from Project specific electricity consumption

Elec $\mathrm{CO} 2=($ ELtotal $*$ EFEL $) / 2204.62$

Where: 


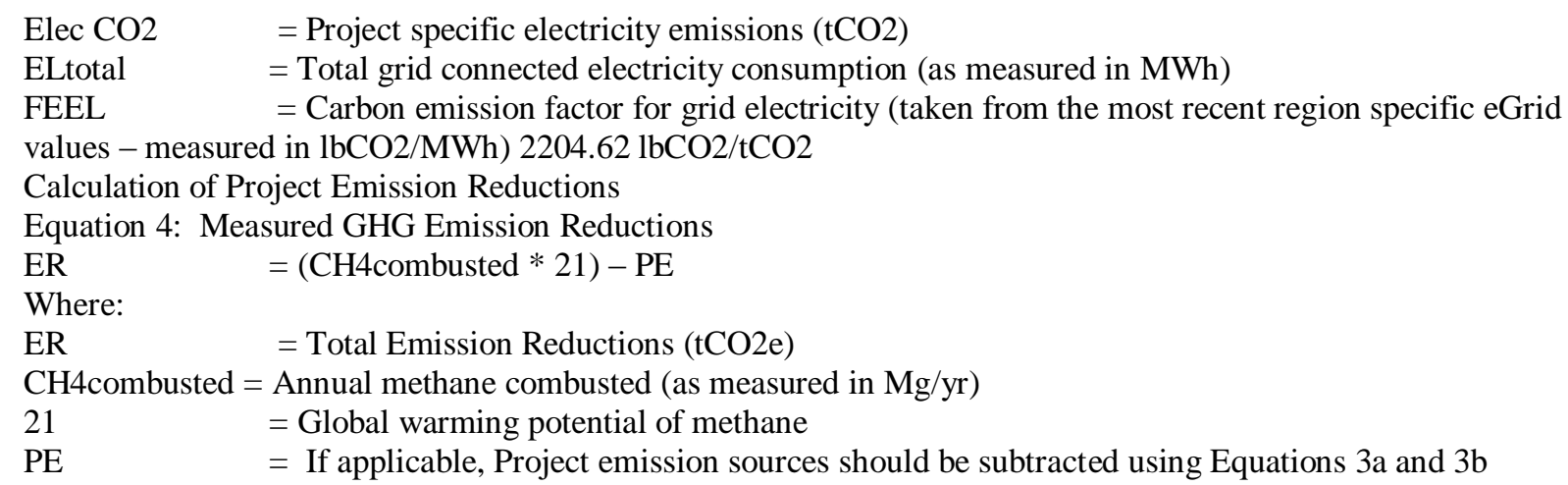

\subsection{Reporting and Record-Keeping Requirements}

The Project Proponent must maintain all relevant data and documentation related to renewable energy production and monitoring equipment as required. All relevant project documentation shall be kept for a minimum of 2 years beyond each verification time-period.

\subsection{Carbon Trading Price}

In the United States, some of the companies involved in carbon credit trading are the Chicago Climate Exchange, AgraGate, and the Environmental Credit Corporation. Trading prices have been variable. For the Chicago Climate Exchange, the price per metric ton of $\mathrm{CO}_{2}$ in 2008 went from $\$ 2$ in early 2008 to $\$ 7$ in midsummer, and back to $\$ 2$ in the fall

\subsection{Gas Production}

\section{Results and Discussions}

Carbon Credit is the function of Methane recovery from the sewage treatment plants. Methane recovery is the function of biogas production. Biogas production is the function of Volatile solids reduction. Volatile solids reduction is the function of Total suspended solids removal. Total suspended solids removal is the function of volume of sludge and method of treatment. Volume of sludge is the function of quantity of waste water. The gas production can be calculated as follows.

Total suspended solids in the influent $\quad=450 \mathrm{mg} / \mathrm{l}$

Total suspended solids in the effluent $\quad=30 \mathrm{mg} / \mathrm{l}$

Total suspended solids removed $\quad=420 \mathrm{mg} / \mathrm{l}$

Assuming volatile solids to be equal to $70 \%$ of suspended solids, we have

Volatile solids removed $\quad=70 \%$ X $420 \mathrm{mg} / \mathrm{l}$.

$$
=294 \mathrm{mg} / \mathrm{l}
$$

Now assuming that the volatile solids (matter) is reduced by $65 \%$ in the sludge by digestion, we have

Volatile solids reduced $\quad=65 \%$ X $294=191.1 \mathrm{mg} / \mathrm{l}$

Therefore Volatile matter reduced per million litre of sewage

$$
=191.1 \times 10^{6} / 10^{6} \quad=191.1 \mathrm{~kg}
$$

Now assuming that $0.9 \mathrm{~m} 3$ of gas is produced per $\mathrm{kg}$ of volatile matter reduced, we have, the gas produced/ million litre of sewage

\subsection{Calorific Value of Biogas \\ $\mathrm{CH} 4=65 \mathrm{vol} \% ; \mathrm{CO} 2=32 \mathrm{vol} \%$}

Calorific value of pure $\mathrm{CH} 4$

Calorific value of biogas

$(0.65 \mathrm{X} 16$ X 50,000)/ $(0.65 \mathrm{X} 16+0.32 \mathrm{X} 44)$

Avg. mole wt.

Volume per unit weight

C.V. of biogas

$(\mathrm{m} 3 / \mathrm{kg})]$

Projected Electricity

Efficiency of Gas engine, $\eta=30 \%$,

Actual Electricity

$$
=0.9 \times 191.1=171.99 \mathrm{~m}^{3} \text { (or) }=172 \mathrm{~m}^{3}
$$

$$
=50,000 \mathrm{~kJ} / \mathrm{kg}
$$

$$
\begin{aligned}
& =21241.8 \mathrm{~kJ} / \mathrm{kg} \\
& =0.65 \times 16+0.35 \times 44 \\
& =25.8 \mathrm{~kg} / \mathrm{k} \cdot \mathrm{mole} \\
& =22.414 / \mathrm{mol} \mathrm{wt} .(\mathrm{m} 3 / \mathrm{kg}) \\
& =22.414 / 25.8 \\
& =21241.8 \mathrm{~kJ} / \mathrm{kg}
\end{aligned}
$$$$
=21.24 \mathrm{MJ} / \mathrm{kg}
$$$$
=24450 / 3600[1 \mathrm{~J}=1 \text { watt sec }] \quad=6.792 \mathrm{kWh} / \mathrm{m}^{3}
$$$$
=6.792 \times 0.30 \quad=2.04 \mathrm{kWh} / \mathrm{m}^{3}
$$ 
C. Power Generation as Per the Production of Biogas

Table III

Theoretical gas production

Gas produced per million litre of sewage $=172 \mathrm{~m} 3$

\begin{tabular}{|l|l|l|l|}
\hline Sl.No & Location of STP & Capacity in MLD & $\begin{array}{l}\text { Theoretical gas production } \\
\text { in m3 }\end{array}$ \\
\hline 1 & Kodunkaiyur & 110 & 18920 \\
\hline 2 & Koyambedu & 60 & 10320 \\
\hline 3 & Nesappakkam & 40 & 6880 \\
\hline 4 & Perungudi & 114 & 19608 \\
\hline & Total & 324 & $55728 \mathrm{~m} 3$ \\
\hline
\end{tabular}

Table IV

Energy Production from Biogas Energy production for $1 \mathrm{~m} 3$ biogas @ 21.24 MJ $/ \mathrm{m} 3=2.04 \mathrm{kWh}$

\begin{tabular}{|c|l|c|c|}
\hline $\begin{array}{c}\text { Sl. } \\
\text { No }\end{array}$ & \multicolumn{1}{|c|}{ Location of STPs } & Biogas production in m3 & \multicolumn{1}{c|}{$\begin{array}{c}\text { Energy production /day } \\
\text { MWh/day }\end{array}$} \\
\hline 1 & Kodunkaiyur & 18920 & 38.60 \\
\hline 2 & Koyambedu & 10320 & 21.05 \\
\hline 3 & Nesappakkam & 6880 & 14.04 \\
\hline 4 & Perungudi & 19608 & 40.00 \\
\hline \multicolumn{2}{|c|}{ Total Energy production per day MWh/day } & $113.69 \mathrm{MWh}$ \\
\hline \multicolumn{2}{|l|}{ Annual Electricity Production: 113.69 MWh X 270 days (9 } & $30696 \mathrm{MWh}$ \\
\hline \multicolumn{2}{|l|}{ Total Electricity savings per year@ Rs4.20 per unit } & Rs. 1289.00 lakhs \\
\hline
\end{tabular}

3.3 Calculations for Metered Methane Destruction

Equation 1:

$\mathrm{CH} 4$ recovered $=$ BGrecovered $\mathrm{x} \% \mathrm{CH} 4$

CH4recovered $=55728 \mathrm{~m} 3 \times 0.65=36223 \mathrm{~m} 3 * 35.32 \mathrm{cft}$

$$
=1279396 \mathrm{ft}^{3} / \text { day }
$$

Due to seasonal variation, only 270 days in an year will be taking into account

Equation 2:

$\mathrm{CH} 4$ combusted $=345436920 \mathrm{ft}^{3} /$ year

$\mathrm{CH} 4$ combusted

$$
\begin{aligned}
& =(\text { CH4recovered } \times 16.04 \times[1 / 106] *[1 / 24.04] \times 28.32) * \mathrm{DE} \\
& =\left(345436920 \mathrm{ft}^{3} \times 16.04 \times\left[1 / 10^{6}\right] *[1 / 24.04] \times 28.32\right) * 0.98=6396.73
\end{aligned}
$$

metric tons per year

Calculation of Project Emissions

Depending on Project-specific circumstances, certain emissions sources may need to be subtracted from total

Project emission reductions using the equations below.

Equation 3a:

CO2 Emissions from Fossil Fuel Combustion

$$
\text { DestCO2 }=\Sigma \mathrm{y}(\mathrm{FFy} * \mathrm{EFy})=\text { Zero }
$$

(since there will be no Fossil Fuel required for the biogas conversion)

Equation 3b:

$\mathrm{CO} 2$ emissions from Project specific electricity consumption

Elec $\mathrm{CO} 2$

$=($ ELtotal $*$ EFEL) $/ 2204.62=$ Zero (since there will be no electricity

required for the biogas conversion)

Calculation of Project Emission Reductions

Equation 4:

Measured GHG Emission Reductions

ER

$\mathrm{ER}=(6396.73 * 21)$

Carbon Trading price
$=(\mathrm{CH} 4$ combusted $* 21)-\mathrm{PE}$

$=134331.33$ metric tons per year

$=\$ 2$ per metric tons $* 134331.33$

$=\$ 268663$

3.4 Carbon Trading Opportunities in India

The total waste water generation in class I cities is 16,662.5 MLD. As per Indian conditions, the minimum total suspended solids in the influent are $200 \mathrm{mg} / \mathrm{l}$. and the maximum total suspended solids in the influent are 500 $\mathrm{mg} / \mathrm{l}$. So, taking average total suspended solids in the influent as $350 \mathrm{mg} / \mathrm{l}$; Total suspended solids in the influent is $350 \mathrm{mg} / \mathrm{l}$; Total suspended solids in the effluent is $30 \mathrm{mg} / \mathrm{l}$. \& Total suspended solids removed is $320 \mathrm{mg} / \mathrm{l}$. 
Assuming volatile solids to be equal to $70 \%$ of suspended solids,

We have Volatile solids removed $=70 \%$ X $320 \mathrm{mg} / \mathrm{l}$.

$=224 \mathrm{mg} / \mathrm{l}$.

Now assuming that the volatile solids (matter) is reduced by $65 \%$ in the sludge by digestion, we have Volatile solids reduced

$$
\begin{aligned}
& =65 \% \text { X } 224 \\
& =145.6 \mathrm{mg} / 1 .
\end{aligned}
$$

Therefore Volatile matter reduced / million litre of sewage

$$
\begin{aligned}
& =145.6 \times 10^{6} / 10^{6} \\
& =145.6 \mathrm{~kg}
\end{aligned}
$$

Now assuming that $0.9 \mathrm{~m} 3$ of gas is produced / $\mathrm{kg}$ of volatile matter reduced, we have

The gas produced per million litre of sewage

$$
\begin{aligned}
& =0.9 \times 145.6 \\
& =131.04 \mathrm{~m} 3 \text { (or) } \\
& =131 \mathrm{~m} 3
\end{aligned}
$$

Biogas production

The total waste water generation in class I cities is $16,662.5 \mathrm{MLD}$.

$$
\begin{aligned}
& =16,662.5 \times 131 \\
& =2182787.5 \mathrm{~m}^{3}
\end{aligned}
$$

Considering one-forth of the volume, we have, $545697 \mathrm{~m}^{3}$ of biogas production.

$\begin{array}{ll}\text { Biogas production } & =545697 \mathrm{~m}^{3} \\ \text { C.V.of Biogas } & =21.24 \mathrm{MJ} / \mathrm{kg}\end{array}$

$=21.24 \mathrm{MJ} / \mathrm{kg}$

Energy production for $1 \mathrm{~m} 3$ biogas @ $21.24 \mathrm{MJ} / \mathrm{m}^{3}$

$$
\begin{aligned}
& =2.04 \mathrm{kWh} / \text { day } \\
& =545697 \mathrm{X} 2.04 \\
& =1113221.88 \mathrm{kWh} / \text { day } \\
& =1113.22 \mathrm{MWh} / \text { day. (Say) } \\
= & 1100 \mathrm{MWh} / \text { day }
\end{aligned}
$$

Annual Power Production: 1100MWh X 270 days

=297000 MWh@ @s. 4.00per unit (average), total Electricity savings per year $=297000 \times 4.00 \times 1000$

$$
=\text { Rs. } 118.80 \text { crores. }
$$

$\mathrm{CH}_{4}$ recovered $=545697 \mathrm{~m} 3 \times 0.65=354703 \mathrm{~m} 3 * 270$

$=95769810 \mathrm{~m} 3 /$ year

$\mathrm{CH}_{4}$ combusted $=\left(95769810 \mathrm{~m} 3 \times 35.32 \times 16.04 \times\left[1 / 10^{6}\right] *[1 / 24.04] \times 28.32\right) * 0.98$

$=62638.10$ metric tons per year

GHG Emission Reductions ER $\quad=62638.10 * 21)$

$=1315400.1$ metric tons per year

Carbon Trading price

$$
=\$ 2 \text { per metric tons } * 1315400.1
$$

$$
=\$ 2630800
$$

\section{Conclusion}

Sewage treatment plants designed for resource recovery are less expensive to operate than traditional aerobic plants. We need the right kind of sewage treatment. The ASP and UASB based sewage treatment plant are biogas producing plants. The FAB, SBR and WSP based plants are not capable of producing biogas.

Chennai city has a total sewage treatment capacity of 541MLD. All the plants are equipped with Activated Sludge Process technology. Out of which, only 324 MLD capacity of plants are having biogas conversion technology. 217 MLD of plants are old plants and are not having the technology of biogas conversion. From the available technology, the theoretical CER per annum is 134331.33 metric tons. Assuming the Carbon Trading price as $\$ 2$ per metric tons, we can earn $\$ 268663$ per year.

The total waste water generation in class I cities is 16,662.5 MLD. Considering one-forth of the volume, we have, $545697 \mathrm{~m}^{3}$ of biogas production. The annual Power Production: 297000 MWh @ Rs. 4.00 per unit (average), the total electricity savings per year is Rs. 118.80 crores. If all waste waters are properly managed only in class I cities in India, we will get Rs. 118.80 crores/year in future through the power production from biogas. The GHG Emission Reductions is calculated as 1315400.1 metric tons per year. Assuming the Carbon Trading price as \$2 per metric tons, we can earn $\$ 2630800$ per year. 


\section{Reference}

[1] Clean Development Mechanism (CDM) and Carbon Trading in India by Jitendra Kumar Singh, 1 Assistant Manager - Environment, TCE Consulting Engineers Ltd.

[2] Chicago Climate Exchange Offset Project Protocol - Agricultural Methane Collection \& Combustion Updated as of 9/30/2009

[3] Chennai Metropolitan Water Supply and Sewerage Board (CMWHSS Board), 'Sewage Treatment Plants Project Report 2006-2007'.

[4] National Atlas \& Thematic Mapping Organization, 'The Environmental Atlas of India', Kolkata, 2001.

\section{Authors Profile}

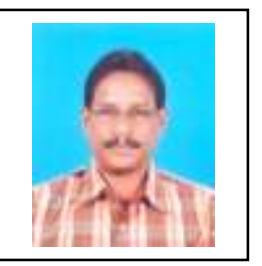

Suresh kumar D received the M.Tech. degree in Conservation of Rivers and Lakes from the Indian Institute of Technology, Roorkee, India, in 2007.Currently doing $\mathbf{P h D}$ in Civil Engineering Department at Karpagam University, Coimbatore, India. His research interest includes urban water supply and sewerage systems, sewage treatment plants, limnology, and Artificial Neural Network.

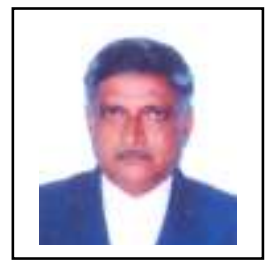

Dr.Sekaran $\mathbf{V}$ received the M.E. degree in Public Health engineering from Bharathiyar University, Coimbatore, India, in 1985 and also received $\mathbf{P h D}$ in Civil Engineering at Anna University, Chennai, India in 2009. His research interest includes urban water supply and sewerage systems, sewage treatment plants, limnology, and Artificial Neural Network. 